\title{
Antimicrobial activity of red wine and oenological extracts against periodontal pathogens in a validated oral biofilm model
}

María C. Sánchez ${ }^{1}$ D, Honorato Ribeiro-Vidal' ${ }^{1}$ Adelaida Esteban-Fernández², Begoña Bartolomé2 ${ }^{2}$ Elena Figuero ${ }^{1}$, María V. Moreno-Arribas², Mariano Sanz ${ }^{1}$ and David Herrera ${ }^{1,3^{*}}$

\begin{abstract}
Background: Previous research findings support an antimicrobial effect of polyphenols against a variety of pathogens, but there is no evidence of this effect against periodontal pathogens in complex biofilms. The purpose of this study was to evaluate the antimicrobial activity of red wine and oenological extracts, rich in polyphenols, against the periodontal pathogens Porphyromonas gingivalis, Aggregatibacter actinomycetemcomitans and Fusobacterium nucleatum and total bacteria growing in an in vitro oral biofilm static model.

Methods: A previously validated biofilm model, including Streptococcus oralis, Actinomyces naes/undii, Veillonella parvula, F. nucleatum, P. gingivalis and A. actinomycetemcomitans was developed on sterile hydroxyapatite discs. Red wine (and dealcoholized wine), and two polyphenols-rich extracts (from wine and grape seeds) were applied to $72 \mathrm{~h}$ biofilms by dipping the discs during 1 and $5 \mathrm{~min}$ in the wine solutions and during $30 \mathrm{~s}$ and $1 \mathrm{~min}$ in the oenological extracts. Resulting biofilms were analyzed by confocal laser scanning microscopy and viable bacteria (colony forming units $/ \mathrm{mL}$ ) were measured by quantitative polymerase chain reaction combined with propidium monoazide. A generalized linear model was constructed to determine the effect of the tested products on the viable bacterial counts of A. actinomycetemcomitans, P. gingivalis and F. nucleatum, as well on the total number of viable bacteria.
\end{abstract}

Results: The results showed that red wine and dealcoholized red wine caused reduction in viability of total bacteria within the biofilm, with statistically significant reductions in the number of viable $P$. gingivalis after 1 min $(p=0.008)$ and in A. actinomycetemcomitans after 5 min of exposure $(p=0.011)$ with red wine. No evidence of relevant antibacterial effect was observed with the oenological extracts, with statistically significant reductions of $F$. nucleatum after $30 \mathrm{~s}$ of exposure to both oenological extracts $(p=0.001)$.

Conclusions: Although moderate, the antimicrobial impact observed in the total bacterial counts and counts of $A$. actinomycetemcomitans, $P$. gingivalis and F. nucleatum, encourage further investigations on the potential use of these natural products in the prevention and treatment of periodontal diseases.

Keywords: Red wine, Oenological extracts, Polyphenols, Periodontal diseases, P. gingivalis, A. actinomycetemcomitans, F. nucleatum

\footnotetext{
* Correspondence: davidher@ucm.es

'ETEP (Etiology and Therapy of Periodontal Diseases) Research Group,

University Complutense, Madrid, Spain

${ }^{3}$ Department of Dental Clinical Specialities (DDCS), Faculty of Odontology,

Plaza Ramón y Cajal s/n Ciudad Universitaria, 28040 Madrid, Spain

Full list of author information is available at the end of the article
}

(c) The Author(s). 2019 Open Access This article is distributed under the terms of the Creative Commons Attribution 4.0 International License (http://creativecommons.org/licenses/by/4.0/), which permits unrestricted use, distribution, and reproduction in any medium, provided you give appropriate credit to the original author(s) and the source, provide a link to the Creative Commons license, and indicate if changes were made. The Creative Commons Public Domain Dedication waiver (http://creativecommons.org/publicdomain/zero/1.0/) applies to the data made available in this article, unless otherwise stated. 


\section{Background}

Dental biofilms located at the interface between the teeth and the gingiva are mainly composed of microbial communities encompassing hundreds of different bacterial species. In gingival health, these biofilms are typically comprised of Gram-positive facultative aerobic bacteria, while in presence of gingival inflammation, such as in gingivitis and periodontitis, these biofilms increase in volume and complexity [1]. These changes result in an increment of Gram-negative bacteria and well-recognized pathogens such as Porphyromonas gingivalis, Prevotella intermedia, Tannerella forsythia or Treponema denticola, as well as Aggregatibacter actinomycetemcomitans [2, 3]. In fact, the etiology of periodontal diseases is currently conceived as a dysbiosis between the bacteria present in dental biofilms and the host response against this bacterial challenge, which would be responsible of the clinical expression of either gingivitis or periodontitis [4].

Prevention and treatment of periodontal diseases mainly consist on strategies to eliminate or reduce these biofilms, either mechanically or chemically (antiseptic and/or systemic or locally applied antimicrobial agents) [5, 6]. However, the widespread use of antibiotics has several unwanted effects, such as the development of bacterial resistances, alterations of the gut microbiota or even direct renal and hepatic damage $[7,8]$. Similarly, certain commonly used antiseptics can cause irritation of the oral mucosa, tooth staining or increased dental calculus formation [9]. All these facts indicate the need to develop novel antimicrobial strategies useful for the management of periodontal diseases.

In recent years, scientific evidence has emerged on the potential use of naturally derived phenolic compounds in the prevention/treatment of many chronic diseases, such as cardiovascular, metabolic, or neurodegenerative diseases and, to a lesser extent some cancers [10-13]. Most of these diseases have an inflammatory base and some may be triggered by bacteria. Consequently, there is potential for the use of natural polyphenols, that may exhibit both anti-bacterial and anti-inflammatory properties. It can be therefore hypothesized that phenolic compounds, such as polyphenols could be potentially effective in the prevention and treatment of oral diseases [14].

The anti-inflammatory properties of natural polyphenols have been extensively studied [10], even in relation to the periodontal diseases [14]. In regards to their possible anti-antibacterial effect, previous studies have described different ways of actions; either associated with the ability of polyphenols to generate hydroxyl radicals which would produce $\mathrm{H}_{2} \mathrm{O}_{2}$ and subsequent damage in the bacterial DNA and in its membrane integrity [15], or by altering the structure of the bacterial cell membrane leading to exit of intracellular components, or by changing the intracellular exchange of protons and potassium and phosphate ions [16-18].

Polyphenols are naturally occurring compounds largely found in fruits (i.e., grape, apple, pear or cherry), in cereals, dry fruits, chocolate, and also in beverages (i.e., wine, coffee, beer and tea) [19]. Red wine and grapes are rich sources of phenolic compounds [20]. Its antibacterial action has been evaluated with evidence of inhibitory action on the growth of different Streptococcus spp. strains and other bacteria associated with dental caries [21-25]. Also, the effect of polyphenol-rich foods (including several types of tea and wine), lead up as mouth rinses, has been investigated by assessing their inhibitory activity on oral pathogens and on the bacterial adherence to oral tissues [26-28]. However, there are few studies assessing the possible effect of phenolic natural extracts on multi-species biofilms, or specifically on the periodontal pathogens associated with the etiology of periodontal diseases [22, 23, 28-32].

Therefore, the present work aims to evaluate the antimicrobial potential of red wine and dealcoholized red wine, as well as of two oenological extracts (a red wine extract and a grape seed extract), on an in vitro multispecies biofilm model that emulates subgingival biofilms and includes periodontal pathogens such as $P$. gingivalis, A. actinomycetemcomitans and F. nucleatum.

\section{Methods}

\section{Red wines}

A young red wine was used in this investigation (var. Pinot Noir, vintage 2010), provided by Bodegas Miguel Torres S.A. (Vilafranca del Penedès, Barcelona, Spain). The phenolic content present in the wine include: total anthocyanins $=0.447 \mathrm{mg}$ of malvidin-3-glucoside $\mathrm{mL}^{-1}$, total catechins $=1.612 \mathrm{mg}$ of $(+)$-catechin $\mathrm{mL}^{-1}$ and total polyphenols $=1.758 \mathrm{mg}$ of gallic acid equiv. $\mathrm{mL}^{-1}$. The principal individual phenolic compounds found in this wine were flavan-3-ols, flavonols, alcohols, anthocyanins, stilbenes and hydroxycinnamic acids, determined by Ultra-High-Performance Liquid ChromatographyElectroSpray Ionization-tandem Mass spectrometry (UHPLC-ESI-MS/MS) for other studies [33].

A rotary evaporator was used for the preparation of dealcoholized red wine, removing the $\mathrm{EtOH}$ and adding distilled water to reconstitute it until the original volume.

\section{Oenological extracts}

Two commercially available oenological phenolic extracts were used: Provinols ${ }^{\mathrm{Tm}}$, a red wine extract, kindly supplied by Safic-Alcan Especialidades S.A.U. (Barcelona, Spain) and a grape seed extract, Vitaflavan', kindly provided by Piriou (Les Derives Resiniques \& Terpeniques S.A., France). The total phenolic content of the extracts was $474 \mathrm{mg}$ of gallic acid equiv. $\mathrm{g}^{-1}$ for Provinols ${ }^{\mathrm{Tm}}$ and $629 \mathrm{mg}$ 
of gallic acid equiv. $\mathrm{g}^{-1}$ for Vitaflavan. The phenolic compositions of both oenological extracts has been determined by UHPLC-ESI-MS/MS in previous studies [34, $35]$. Both the wine extract and grape seed extracts were dissolved in distilled water containing $4 \%$ dimethyl sulfoxide (DMSO) $(\mathrm{v} / \mathrm{v})$, until reaching a final concentration of $20 \mathrm{mg} \mathrm{mL}^{-1}$.

\section{Bacterial strains and culture conditions}

Six bacterial strains, including Streptococcus oralis CECT 907 T, Veillonella parvula NCTC 11810, Actinomyces naeslundii ATCC 19039, F. nucleatum DMSZ 20482, A. actinomycetemcomitans DSMZ 8324 and $P$. gingivalis ATCC 33277 were used. Bacteria were cultured in blood agar plates (Blood Agar Oxoid No 2; Oxoid, Basingstoke, UK), supplemented with $5 \%(\mathrm{v} / \mathrm{v})$ sterile horse blood (Oxoid), $5.0 \mathrm{mg} \mathrm{L}^{-1}$ hemin (Sigma, St. Louis, MO, USA) and 1.0 $\mathrm{mg} \mathrm{L}^{-1}$ menadione (Merck, Darmstadt, Germany) at $37^{\circ} \mathrm{C}$ for $24-72 \mathrm{~h}$ in anaerobic conditions $\left(10 \% \mathrm{H}_{2}, 10 \%\right.$ $\mathrm{CO}_{2}$, and balance $\mathrm{N}_{2}$ ).

\section{Biofilm development}

A multi-species in vitro biofilm model was developed as previously described by Sánchez and colleagues [36]. For the inoculum preparation, the microorganisms were individually cultivated in anaerobic conditions on a protein rich medium containing brain-heart infusion (BHI) (Becton, Dickinson and Company, USA) supplemented with $2.5 \mathrm{~g}$ $\mathrm{L}^{-1}$ mucin (Oxoid, Thermo Scientific, Hampshire, UK), 1.0 $\mathrm{g} \mathrm{L}^{-1}$ yeast extract (Oxoid, Thermo Scientific, Hampshire, UK), $0.1 \mathrm{~g} \mathrm{~L}^{-1}$ cysteine (Sigma-Aldrich, Barcelona, Spain), $2.0 \mathrm{~g} \mathrm{~L}^{-1}$ sodium bicarbonate (Merck, NJ, USA), $5.0 \mathrm{mg} \mathrm{L}^{-1}$ hemin (Sigma-Aldrich, Barcelona, Spain), $1.0 \mathrm{mg} \mathrm{L}^{-1}$ menadione (Merck, NJ, USA) and $0.25 \%(\mathrm{v} / \mathrm{v})$ glutamic acid (Sigma-Aldrich, Barcelona, Spain). The bacterial cultures were harvested at mid-exponential phase (measured by spectrophotometry), and a mixed bacteria suspension in modified BHI medium containing $10^{3}$ colony-forming units (CFU) $\mathrm{mL}^{-1}$ for $S$. oralis, $10^{5} \mathrm{CFU} \mathrm{mL}^{-1}$ for $V$. parvula and A. naeslundii, and $10^{6} \mathrm{CFU} \mathrm{mL}^{-1}$ for F. nucleatum, $A$. actinomycetemcomitans and $P$. gingivalis was prepared. The biofilms were grown on sterile calcium hydroxyapatite (HA) discs of $7 \mathrm{~mm}$ of diameter and $1.8 \mathrm{~mm}$ (standard deviation, $\mathrm{SD}=0.2$ ) of thickness (Clarkson Chromatography Products, Williamsport, PA, USA) discs deposited in 24wells cell culture plates (Greiner Bio-one, Frickenhausen, Germany), inoculating each well with $1.5 \mathrm{~mL}$ of mixed bacteria, for $72 \mathrm{~h}$ at $37{ }^{\circ} \mathrm{C}$ in anaerobic condition. All assays were performed independently at least three times and in triplicate $(n=9)$.

\section{Antimicrobial activity}

The antimicrobial activity of wines and oenological extracts was examined on $72 \mathrm{~h}$ biofilms by determining the reduction in the number of viable $\mathrm{CFU} \mathrm{mL} \mathrm{m}^{-1}$ using the quantitative polymerase chain reaction (qPCR). For the oenological extracts, 30 and $60 \mathrm{~s}$ were selected as exposure times since they are bioactive products, commercially available, and for them, the standard exposure times established for other antimicrobial commercially available products (e.g. products with chlorhexidine), was selected [37-39]. On the other hand, in the case of wine solutions, the product was considered as a new possible bioactive agent, evaluated for the first time, therefore, not only the standard $60 \mathrm{~s}$ interval was selected as exposure time, but also an "extreme" exposure time of $5 \mathrm{~min}$, with the aim of detecting any possible effect of red wine solutions (dealcoholized or not). Two different protocols were performed:

- For red wine (dealcoholized or not), biofilms were dipped during 1 and $5 \mathrm{~min}$ in the wine solutions at room temperature. Phosphate buffer saline (PBS) was used as negative control and, in order to discard a bactericidal effect of the $\mathrm{EtOH}$ contained in the wine, also $12 \%$ ethanol was applied.

- For the oenological extracts, biofilms were dipped during $30 \mathrm{~s}$ and $1 \mathrm{~min}$ at room temperature, due to their high phenolic content. PBS was used as negative control, and in order to discard a bactericidal effect of the DMSO used for dissolve the extracts, 4\% DMSO solution was also tested.

\section{Microbiological outcomes}

After the antimicrobial treatment, biofilms were sequentially rinsed in $2 \mathrm{~mL}$ of sterile PBS three times (immersion time per rinse, $10 \mathrm{~s}$ ), in order to remove possible remains of the oenological solutions or extracts and unbound bacteria. Then, biofilms were disrupted by vortex for $2 \mathrm{~min}$ in $1 \mathrm{~mL}$ of PBS. To discriminate between DNA from live and dead bacteria, propidium monoazide (PMA) (Biotium Inc., Hayword, CA, USA) was used. The use of this PMA dye combined with qPCR has shown the ability to detect the DNA from viable bacteria [40]. For this, $100 \mu \mathrm{M}$ of PMA was added to $250 \mu \mathrm{L}$ of disaggregated biofilm. Following an incubation period of $10 \mathrm{~min}$ at $4{ }^{\circ} \mathrm{C}$ in the dark, the samples were subjected to light-exposure for $30 \mathrm{~min}$, using PMALite LED Photolysis Device (Biotium Inc.), and then centrifuged at $12,000 \mathrm{rpm}$ for $3 \mathrm{~min}$ prior to DNA extraction.

Bacterial DNA was isolated from all biofilms using a commercial kit ATP Genomic DNA Mini Kit ${ }^{\circ}$ (ATP biotech. Taipei, Taiwan), following manufacturer's instructions and the hydrolysis 5'nuclease probe assay qPCR method was used for detecting and quantifying the bacterial DNA. The qPCR amplification was performed following a protocol previously optimized by our research 
group, using primers and probes targeted against $16 \mathrm{~S}$ rRNA gene [obtained through Life Technologies Invitrogen (Carlsbad, CA, USA)] [41].

Each DNA sample was analysed in duplicate. Quantification cycle $(\mathrm{Cq})$ values, describing the PCR cycle number at which fluorescence rises above the baseline, were determined using the provided software package (LC 480 Software 1.5; Roche Diagnostic GmbH; Mannheim, Germany) . Quantification of viable cells by qPCR was based on standard curves. The correlation between $\mathrm{Cq}$ values and CFU mL $\mathrm{m}^{-1}$ was automatically generated through informatics analysis (LC 480 Software 1.5; Roche).

All assays were developed with a linear quantitative detection range established by the slope range of 3.33.5 cycles $/ \log$ decade, $r^{2}>0.998$ and an efficiency range of 1.9-2.0.

\section{Confocal laser scanning microscopy (CLSM)}

Non-invasive confocal imaging of fully hydrated biofilms was carried out using a fixed-stage Ix83 Olympus inverted microscope coupled to an Olympus FV1200 confocal system (Olympus; Shinjuku, Tokyo, Japan). LIVE/DEAD ${ }^{\circ}$ BacLight $^{\text {tw }}$ Bacterial Viability Kit solution (Molecular Probes B. V., Leiden, The Netherlands) was used to stained the biofilms at room temperature. The fluorochromes were incubated (ratio 1:1) during $9 \pm 1$ min to obtain the optimum fluorescence signal at the corresponding wave lengths (Syto9: 515-530 nm; Propidium Iodide (PI): $>600 \mathrm{~nm}$. The CLSM software was set to take a z-series of scans (xyz) of $1 \mu \mathrm{m}$ thickness ( 8 bits, $1024 \times 1024$ pixels). Image stacks were analyzed by using the Olympus software (Olympus). Image analysis and live/dead cell ratio (i.e. the area occupied by living cells divided by the area occupied by dead cells) was performed with Fiji software (ImageJ Version 2.0.0-rc-65 / $1.52 \mathrm{~b}$, Open source image processing software).

\section{Statistical analyses}

The selected outcome variables to study the antibacterial effect of wine solutions and oenological extracts were the counts of viable bacteria present on the biofilms, expressed as viable CFU mL $\mathrm{mL}^{-1}$ of A. actinomycetemcomitans, $P$. gingivalis, $F$. nucleatum and total bacteria by qPCR, and the live/dead cell ratio of the whole biofilm by CLSM. An experiment-level analysis was performed for each parameter of the study ( $n=9$ for qPCR and $n=$ 3 for CLSM results). Shapiro-Wilk goodness-of-fit tests and distribution of data were used to assess normality. Data were expressed as means $\pm \mathrm{SD}$.

In the case of the experiments with red wine, the effect of each solution [red wine (dealcoholized or not), PBS and $12 \% \mathrm{EtOH}$, the time of exposure (1 or $5 \mathrm{~min}$ ) and their interaction with the main outcome variable (counts expressed as CFU $\mathrm{mL}^{-1}$ or live/dead cell ratio), was compared by means of a parametric ANOVA test for independent samples, and a general linear model was constructed for each bacterium (A. actinomycetemcomitans, $P$. gingivalis and $F$. nucleatum) and for total bacteria for qPCR results and for total bacteria for live/dead cell ratio of whole biofilm obtained by CLSM, using the method of maximum likelihood and Bonferroni corrections for multiple comparisons. A similar model was constructed in the case of the experiments with oenological extracts, in order to compare the effect of each solution (wine extract, grape seed extract, PBS and DMSO), the time of exposure (30 s or $1 \mathrm{~min}$ ) and their interaction with the main outcome variable $\left(\mathrm{CFU} \mathrm{mL} \mathrm{m}^{-1}\right.$ and live/dead cell ratio of whole biofilms).

Results were considered statistically significant at $p<$ 0.05. A software package (IBM SPSS Statistics 24.0; IBM Corporation, Armonk, NY, USA) was used for all data analysis.

\section{Results}

\section{Antimicrobial effect of red wine}

Table 1 depicts the effects of red wine solutions, dealcoholized or not, compared to PBS and $12 \% \mathrm{EtOH}$, on the counts of viable cells of $A$. actinomycetemcomitans, $P$. gingivalis, $F$. nucleatum and total bacteria.

After $1 \mathrm{~min}$ of exposure to red wine or dealcoholized red wine, no statistically significant effect was measured on the viable counts of $A$. actinomycetemcomitans (CFU $\left.\mathrm{mL}^{-1}\right)(p>0.05)$ when compared to control biofilms (exposed to PBS). Conversely, after $5 \mathrm{~min}$ a significant reduction of viable $A$. actinomycetemcomitans $\left(\mathrm{CFU} \mathrm{mL}{ }^{-}\right.$ $\left.{ }^{1}\right)$ occurred with wine $(p=0.053)$ and dealcoholized red wine $(p=0.011)$ when compared to control biofilms. No statistically significant differences were observed between the two wine solutions at any time $(p>0.05)$. The effect of exposure time (between 1 and $5 \mathrm{~min}$ ) was however, statistically significant for both red wine $(p=0.030)$, and dealcoholized red wine $(p=0.006)$.

After 1 min exposure to red wine solutions, there were statistically significant reductions in the viable counts of P. gingivalis $\left(\mathrm{CFU} \mathrm{mL} \mathrm{m}^{-1}\right)(p=0.008)$. Measurable reductions also occurred after $5 \mathrm{~min}$ of exposure with both red wine and dealcoholized red wine, although no significance differences were observed when compared to biofilms exposed to PBS ( $p>0.05$ in all cases). No statistically significant differences were observed in the effectiveness comparing the two wine solutions at applied times or when comparing exposure times $(p>0.05$ for all cases).

For F. nucleatum, reductions in viable counts were not statistically significant after both 1 and 5 min of exposure (Table 1). No statistically significant differences were observed between the two wine solutions at any time $(p>0.05)$. The effect of exposure time (between 1 and 5 
Table 1 Effect of red wine and dealcoholized red wine on the number of viable bacteria in the in vitro multi-species biofilm [colony forming units, CFU mL ${ }^{-1}$, obtained by quantitative real-time polymerase chain reaction (qPCR)]. Data are expressed as mean \pm standard deviation (SD). PBS: phosphate buffer saline, EtOH: ethanol

\begin{tabular}{|c|c|c|c|c|c|}
\hline & \multirow{3}{*}{$\begin{array}{l}\text { Exposure } \\
\text { time (min) }\end{array}$} & \multicolumn{4}{|c|}{ Viable CFU $\mathrm{mL}^{-1}$ [mean (SD)] in the biofilm } \\
\hline & & \multirow{2}{*}{$\begin{array}{l}\text { Treatment with } \\
\text { PBS }\end{array}$} & \multicolumn{3}{|c|}{ Treatment with the corresponding antimicrobial agent } \\
\hline & & & Red wine & Dealcoholized red wine & $12 \% \mathrm{EtOH}$ \\
\hline \multirow[t]{2}{*}{ A. actinomycetemcomitans } & 1 & $1.9 \times 10^{6}\left(7.6 \times 10^{5}\right)$ & $1.8 \times 10^{6}\left(6.5 \times 10^{5}\right)^{\dagger}$ & $1.9 \times 10^{6}\left(1.2 \times 10^{6}\right)^{\dagger}$ & $8.9 \times 10^{5}\left(5.6 \times 10^{5}\right)$ \\
\hline & 5 & $2.0 \times 10^{6}\left(2.0 \times 10^{6}\right)$ & $7.7 \times 10^{5}\left(5.1 \times 10^{5}\right)^{*}+$ & $5.1 \times 10^{5}\left(4.5 \times 10^{5}\right)^{*}+$ & $1.1 \times 10^{6}\left(8.6 \times 10^{5}\right)$ \\
\hline \multirow[t]{2}{*}{ P. gingivalis } & 1 & $1.5 \times 10^{5}\left(1.3 \times 10^{5}\right)$ & $3.4 \times 10^{4}\left(3.5 \times 10^{4}\right)^{*}$ & $5.9 \times 10^{4}\left(5.1 \times 10^{4}\right)$ & $1.2 \times 10^{5}\left(1.4 \times 10^{5}\right)$ \\
\hline & 5 & $4.2 \times 10^{4}\left(3.3 \times 10^{4}\right)$ & $5.2 \times 10^{3}\left(3.2 \times 10^{3}\right)$ & $5.3 \times 10^{3}\left(5.6 \times 10^{3}\right)$ & $3.9 \times 10^{4}\left(1.4 \times 10^{4}\right)$ \\
\hline \multirow[t]{2}{*}{ F. nucleatum } & 1 & $1.4 \times 10^{5}\left(7.1 \times 10^{4}\right)$ & $1.1 \times 10^{5}\left(9.1 \times 10^{4}\right)^{\dagger}$ & $1.2 \times 10^{5}\left(1.0 \times 10^{5}\right)^{\dagger}$ & $8.1 \times 10^{4}\left(8.5 \times 10^{4}\right)$ \\
\hline & 5 & $9.2 \times 10^{4}\left(9.5 \times 10^{4}\right)$ & $3.4 \times 10^{4}\left(3.1 \times 10^{4}\right)^{\dagger}$ & $1.9 \times 10^{4}\left(1.6 \times 10^{4}\right)^{\dagger}$ & $6.5 \times 10^{4}\left(5.6 \times 10^{4}\right)$ \\
\hline \multirow[t]{2}{*}{ Total bacteria } & 1 & $8.2 \times 10^{6}\left(4.2 \times 10^{6}\right)$ & $3.7 \times 10^{6}\left(2.7 \times 10^{6}\right)$ & $3.3 \times 10^{6}\left(2.7 \times 10^{6}\right)$ & $5.9 \times 10^{6}\left(7.9 \times 10^{6}\right)$ \\
\hline & 5 & $7.2 \times 10^{6}\left(3.1 \times 10^{6}\right)$ & $3.9 \times 10^{6}\left(7.2 \times 10^{6}\right)$ & $4.0 \times 10^{6}\left(3.1 \times 10^{6}\right)$ & $3.0 \times 10^{6}\left(1.9 \times 10^{6}\right)$ \\
\hline
\end{tabular}

${ }^{*} p<0.05$, significant differences when compared viable CFU $\mathrm{mL}^{-1}$ to control biofilms (exposed to PBS)

${ }^{\dagger} p<0.05$, significant differences when comparing exposure times for an antimicrobial agent

min) was however, statistically significant for both red wine $(p=0.035)$, and dealcoholized red wine $(p=0.004)$.

In regards to biofilm total bacteria, reductions in viable counts were measured (Table 1) after 1 and 5 min of exposure with both solutions, red wine (45.1 and $54.2 \%$, respectively, of viable bacteria after the exposure when compared to control biofilms) and dealcoholized red wine ( 40.2 and $55.5 \%$, respectively), but differences were not statistically significant (Table 1 ). No statistically significant differences were observed in the effectiveness when comparing red wine and dealcoholized red wine at 1 or $5 \mathrm{~min}$ or when comparing the exposure times $(p>$ 0.05 for all cases).

Due to the possible antibacterial activity of $\mathrm{EtOH}$ present in the red wine, its effect over the three pathogens and total bacteria was evaluated. Although the treatment with $12 \% \mathrm{EtOH}$, emulating the alcoholic content of the wines, resulted in a decrease in total counts (Table 1), no statistically significant differences were observed when compared with PBS ( $p>0.05$ in all cases). No exposure time effect was observed for red wine or dealcoholized red wine, except for $P$. gingivalis, for which the effect of time of exposure (1 min versus 5 min) was statistically significant $(p=0.027)$.

After $72 \mathrm{~h}$ of incubation, CLSM observation revealed the control HA discs were covered by a mature biofilm, with multicellular aggregates well spread through the surface, showing a structural organization based bacterial communities forming microcolonies, with a live/dead cell ratio of $2.04 \pm 0.43$ when dipped in PBS for $1 \mathrm{~min}$ and $1.10 \pm 0.42$ for $5 \mathrm{~min}$ (Fig. $1 \mathrm{a}, \mathrm{b}$ ). When biofilms were dipped in red wine for $1 \mathrm{~min}$, a significant decrease in cell viability of the whole biofilm could be observed ( $p<0.001$; Fig. 1 e; Table 2), demonstrating a $0.74 \pm 0.05$ of live/dead cell ratio, which continued to decrease to $0.53 \pm 0.12$ after $5 \mathrm{~min}$ (Fig. $1 \mathrm{f}$; Table 2). A significant effect was also observed when exposed to dealcoholized red wine for $1 \mathrm{~min}(0.84 \pm 0.23$ of live/dead cell ratio; $p<0.001$; Table 2) and $5 \mathrm{~min}(0.52 \pm 0.03 ; p>0.05)$ (Fig. $1 \mathrm{~g}$, h; Table 2). Visual changes were also appreciated when applying the $12 \% \mathrm{EtOH}$ solution for 1 and $5 \mathrm{~min}$ (live/dead cell ratio of $1.31 \pm 0.26$ and $0.93 \pm 0.12$, respectively; $p=0.018$ after $1 \mathrm{~min}$ of exposure) (Fig. $1 \mathrm{c}, \mathrm{d}$; Table 2). No statistically significant differences were observed when comparing red wine and dealcoholized red wine for 1 or $5 \mathrm{~min}$ or when comparing exposure times ( $p>0.05$ for all cases).

\section{Antimicrobial effects of oenological extracts}

Table 3 depicts the effects of the two polyphenol-rich extracts, compared to the negative control (PBS) and $4 \%$ DMSO, on the number of viable cells of A. actinomycetemcomitans, $P$. gingivalis, $F$. nucleatum and total bacteria.

After $30 \mathrm{~s}$ and $1 \mathrm{~min}$ exposure to the wine and grape seed extracts, there was a reduction in the viable counts of $A$. actinomycetemcomitans, although statistically significant differences were not detected (Table 3). Comparisons between both extract solutions or between the times of exposure for each extract were not statistically significant ( $p>0.05$ in all cases).

Similarly, no significant effect on viable counts of $P$. gingivalis was observed after exposure to the wine and grape seed extracts during $30 \mathrm{~s}$ (Table 3). The number of viable $P$. gingivalis showed reductions when biofilms were treated for $1 \mathrm{~min}$ with the wine extract, but not with the grape seed extract $(p>0.05$ in both cases). No statistically significant differences were observed between the effect reached by the two oenological extracts at any time $(p>0.05$ in both cases). The effect of time of exposure ( $30 \mathrm{~s}$ versus 1 min) was statistically significant for the wine extract 

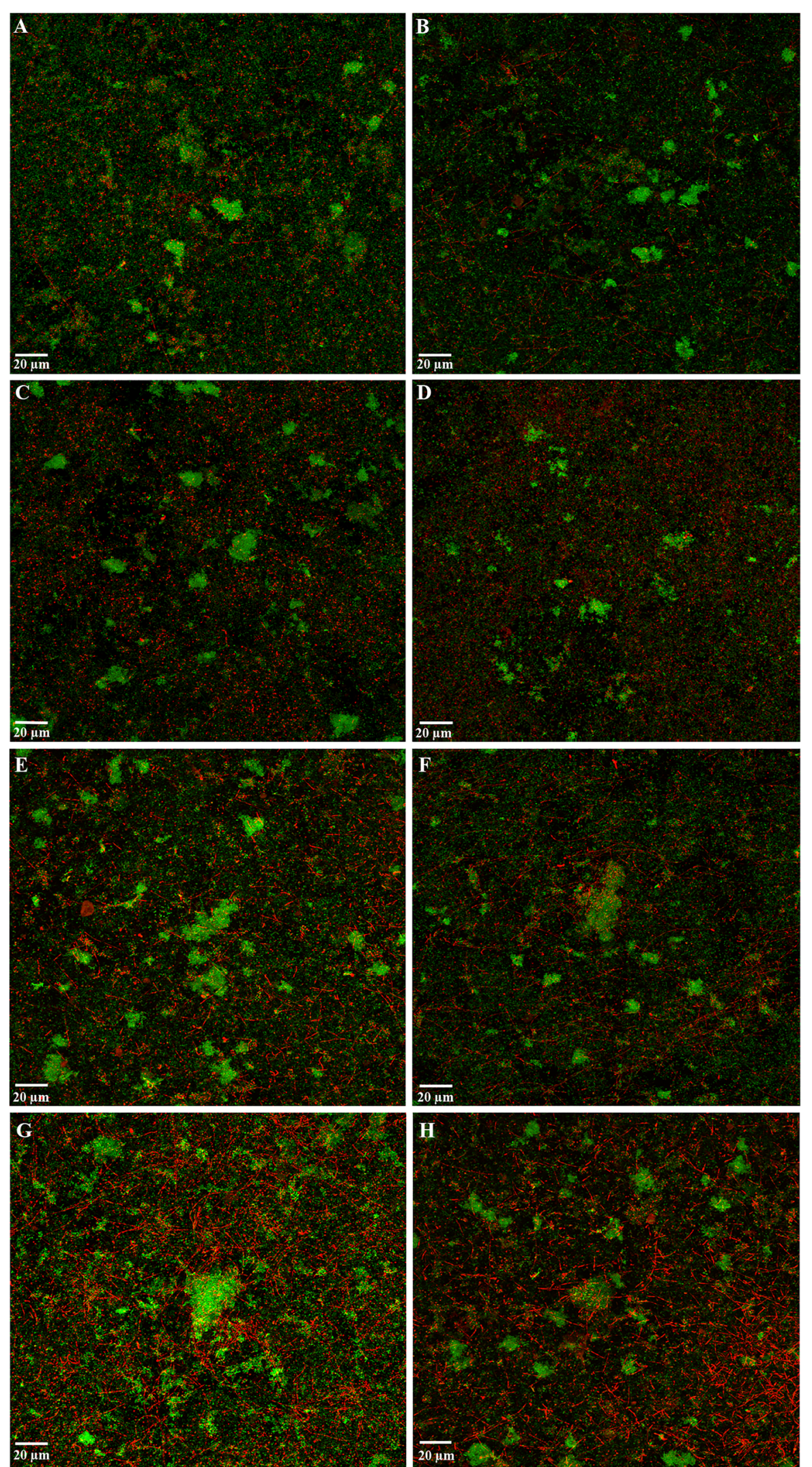

Fig. 1 (See legend on next page.) 
(See figure on previous page.)

Fig. 1 Maximum projection of Confocal Laser Scanning Microscopy (CLSM) images of $72 \mathrm{~h}$ biofilms, growth over hydroxyapatite surfaces, stained with LIVE/DEAD BacLight ${ }^{\top \mathrm{TM}}$ Bacterial Viability Kit, after exposure to: $(\mathbf{a}, \mathbf{b})$ negative control 1 and 5 min, respectively (phosphate buffer saline, PBS); (c, d) 12\% ethanol solution 1 and 5 min, respectively; $(\mathbf{e}, \mathbf{f})$ red wine 1 and 5 min, respectively, and $(\mathbf{g}, \mathbf{h})$ dealcoholized red wine 1 and 5 min, respectively. Scale bar $=20 \mu \mathrm{m}$

$(p=0.014)$, but not for the grape seed extract $(p=$ $0.395)$.

For F. nucleatum, $30 \mathrm{~s}$ of exposure to both oenological extracts significantly reduced viable counts $(p=0.001$, in both cases) (Table 3). However, after $1 \mathrm{~min}$ of exposure to both, although the reduction was maintained, no statistically differences were reached; although the oenological extract showed more effect on F. nucleatum. Similarly, no significant effect was observed when comparing the effect of both extracts at any time or the time of exposure for each one ( $p>0.05$ in all cases).
Regarding the total counts of bacteria included in the biofilm, $30 \mathrm{~s}$ and $1 \mathrm{~min}$ of contact with both, the wine and grape seed extracts, caused a slight reduction in the number of viable counts, but differences were not statistically significant. Similarly, no significant differences were observed between the two extracts at any time. The effect of time of exposure ( $30 \mathrm{~s}$ versus $1 \mathrm{~min}$ ) was statistically significant for the wine extract $(p=0.005)$, but not for the grape seed extract $(p=0.057)$.

Due to the possible antibacterial activity of DMSO, its effect on the tested bacterial species and total bacteria

Table 2 Effect of red wine and dealcoholized red wine on the live/dead cell ratio (i.e. the area occupied by living cells divided by the area occupied by dead cells) of the whole biofilm obtained by Confocal Laser Scanning Microscopy (CLSM). PBS: phosphate buffer saline, EtOH: ethanol

\begin{tabular}{|c|c|c|c|c|c|c|c|}
\hline \multirow{2}{*}{$\begin{array}{l}\text { Exposure } \\
\text { time }\end{array}$} & \multirow[t]{2}{*}{ Chemical treatment } & & \multirow{2}{*}{$\begin{array}{l}\text { Mean } \\
\text { Difference } \\
(I-J)\end{array}$} & \multirow{2}{*}{$\begin{array}{l}\text { Std. } \\
\text { Error }\end{array}$} & \multirow[t]{2}{*}{ Sig. ${ }^{b}$} & \multicolumn{2}{|c|}{ 95\% Confidence Interval for Difference } \\
\hline & & & & & & Lower Bound & Upper Bound \\
\hline \multirow[t]{12}{*}{$1 \mathrm{~min}$} & \multirow[t]{3}{*}{ PBS } & $12 \% \mathrm{EtOH}$ & 0.727 & 0.208 & $0.018^{\mathrm{a}}$ & 0.101 & 1.352 \\
\hline & & Red wine & 1.300 & 0.208 & $0.000^{\mathrm{a}}$ & 0.674 & 1.926 \\
\hline & & Dealcoholized wine & 1.197 & 0.208 & $0.000^{\mathrm{a}}$ & 0.571 & 1.822 \\
\hline & \multirow[t]{3}{*}{$12 \% \mathrm{EtOH}$} & PBS & -0.727 & 0.208 & $0.018^{\mathrm{a}}$ & -1.352 & -0.101 \\
\hline & & Red wine & 0.573 & 0.208 & 0.084 & -0.052 & 1.199 \\
\hline & & Dealcoholized wine & 0.470 & 0.208 & 0.229 & -0.156 & 1.096 \\
\hline & \multirow[t]{3}{*}{ Red wine } & PBS & -1.300 & 0.208 & $0.000^{\mathrm{a}}$ & -1.926 & -0.674 \\
\hline & & $12 \% \mathrm{EtOH}$ & -0.573 & 0.208 & 0.084 & -1.199 & 0.052 \\
\hline & & Dealcoholized wine & -0.103 & 0.208 & 1.000 & -0.729 & 0.522 \\
\hline & \multirow[t]{3}{*}{ Dealcoholized wine } & PBS & -1.197 & 0.208 & $0.000^{\mathrm{a}}$ & -1.822 & -0.571 \\
\hline & & $12 \% \mathrm{EtOH}$ & -0.470 & 0.208 & 0.229 & -1.096 & 0.156 \\
\hline & & Red wine & 0.103 & 0.208 & 1.000 & -0.522 & 0.729 \\
\hline \multirow[t]{12}{*}{$5 \mathrm{~min}$} & \multirow[t]{3}{*}{ PBS } & $12 \% \mathrm{EtOH}$ & 0.177 & 0.208 & 1.000 & -0.449 & 0.802 \\
\hline & & Red wine & 0.577 & 0.208 & 0.082 & -0.049 & 1.202 \\
\hline & & Dealcoholized wine & 0.593 & 0.208 & 0.069 & -0.032 & 1.219 \\
\hline & \multirow[t]{3}{*}{$12 \% \mathrm{EtOH}$} & PBS & -0.177 & 0.208 & 1.000 & -0.802 & 0.449 \\
\hline & & Red wine & 0.400 & 0.208 & 0.435 & -0.226 & 1.026 \\
\hline & & Dealcoholized wine & 0.417 & 0.208 & 0.374 & -0.209 & 1.042 \\
\hline & \multirow[t]{3}{*}{ Red wine } & PBS & -0.577 & 0.208 & 0.082 & -1.202 & 0.049 \\
\hline & & $12 \% \mathrm{EtOH}$ & -0.400 & 0.208 & 0.435 & -1.026 & 0.226 \\
\hline & & dealcoholized wine & 0.017 & 0.208 & 1.000 & -0.609 & 0.642 \\
\hline & \multirow[t]{3}{*}{ Dealcoholized wine } & PBS & -0.593 & 0.208 & 0.069 & -1.219 & 0.032 \\
\hline & & $12 \% \mathrm{EtOH}$ & -0.417 & 0.208 & 0.374 & -1.042 & 0.209 \\
\hline & & Red wine & -0.017 & 0.208 & 1.000 & -0.642 & 0.609 \\
\hline
\end{tabular}

Based on estimated marginal means

${ }^{\text {a }}$ The mean difference is significant at the 0.05 level

${ }^{\mathrm{b}}$ Adjustment for multiple comparisons: Bonferroni 
Table 3 Effect of the red wine phenolic extract (Provinols ${ }^{T M}$ ), rich in anthocyanins, and the oenological extract from grape seeds (Vitaflavan ) on the number of viable bacteria in the in vitro multi-species biofilm [colony forming units, CFU $\mathrm{mL}^{-1}$, obtained by quantitative real-time polymerase chain reaction (qPCR)]. Data are expressed as means \pm standard deviation (SD). PBS: phosphate buffer saline; DMSO: dimethyl sulfoxide

\begin{tabular}{|c|c|c|c|c|c|}
\hline & \multirow{3}{*}{$\begin{array}{l}\text { Exposure } \\
\text { time }\end{array}$} & \multicolumn{4}{|c|}{ Viable CFU $\mathrm{mL}^{-1}$ [mean (SD)] in the biofilm } \\
\hline & & \multirow{2}{*}{$\begin{array}{l}\text { Treatment with } \\
\text { PBS }\end{array}$} & \multicolumn{3}{|c|}{ Treatment with the corresponding antimicrobial agent } \\
\hline & & & Wine extract & Grape seeds extract & $4 \% \mathrm{DMSO}$ \\
\hline \multirow[t]{2}{*}{ A. actinomycetemcomitans } & $30 \mathrm{~s}$ & $7.2 \times 10^{6}\left(6.4 \times 10^{6}\right)$ & $5.8 \times 10^{6}\left(3.8 \times 10^{6}\right)$ & $5.2 \times 10^{6}\left(5.2 \times 10^{6}\right)$ & $5.6 \times 10^{6}\left(3.0 \times 10^{6}\right)$ \\
\hline & $1 \mathrm{~min}$ & $5.2 \times 10^{6}\left(3.7 \times 10^{6}\right)$ & $5.0 \times 10^{6}\left(5.8 \times 10^{6}\right)$ & $2.4 \times 10^{6}\left(1.2 \times 10^{6}\right)$ & $5.2 \times 10^{6}\left(4.9 \times 10^{6}\right)$ \\
\hline \multirow[t]{2}{*}{ P. gingivalis } & $30 \mathrm{~s}$ & $1.7 \times 10^{6}\left(7.0 \times 10^{5}\right)$ & $1.8 \times 10^{6}\left(1.5 \times 10^{6}\right)^{\dagger}$ & $1.3 \times 10^{6}\left(1.5 \times 10^{6}\right)$ & $1.6 \times 10^{6}\left(1.8 \times 10^{6}\right)$ \\
\hline & $1 \mathrm{~min}$ & $8.9 \times 10^{5}\left(6.8 \times 10^{5}\right)$ & $5.0 \times 10^{5}\left(2.6 \times 10^{5}\right)^{\dagger}$ & $8.5 \times 10^{5}\left(4.7 \times 10^{5}\right)$ & $1.0 \times 10^{6}\left(7.0 \times 10^{5}\right)$ \\
\hline \multirow[t]{2}{*}{ F. nucleatum } & $30 \mathrm{~s}$ & $3.8 \times 10^{5}\left(3.1 \times 10^{5}\right)$ & $1.0 \times 10^{5}\left(4.6 \times 10^{4}\right)^{*}$ & $1.1 \times 10^{5}\left(9.2 \times 10^{4}\right)^{*}$ & $3.5 \times 10^{5}\left(1.3 \times 10^{5}\right)^{t}$ \\
\hline & $1 \mathrm{~min}$ & $1.5 \times 10^{5}\left(1.0 \times 10^{5}\right)$ & $3.3 \times 10^{4}\left(2.7 \times 10^{4}\right)$ & $5.4 \times 10^{4}\left(4.2 \times 10^{4}\right)$ & $1.8 \times 10^{5}\left(1.5 \times 10^{5}\right)^{t}$ \\
\hline \multirow[t]{2}{*}{ Total bacteria } & $30 \mathrm{~s}$ & $3.6 \times 10^{7}\left(2.3 \times 10^{7}\right)$ & $2.5 \times 10^{7}\left(1.5 \times 10^{7}\right)^{\dagger}$ & $1.9 \times 10^{7}\left(1.7 \times 10^{7}\right)$ & $1.9 \times 10^{7}\left(1.9 \times 10^{7}\right)$ \\
\hline & $1 \mathrm{~min}$ & $1.3 \times 10^{7}\left(1.1 \times 10^{7}\right)$ & $5.5 \times 10^{6}\left(4.7 \times 10^{6}\right)^{\dagger}$ & $5.6 \times 10^{6}\left(3.4 \times 10^{6}\right)$ & $1.1 \times 10^{7}\left(6.2 \times 10^{6}\right)$ \\
\hline
\end{tabular}

${ }^{*} p<0.05$, significant differences when compared viable CFU $\mathrm{mL}^{-1}$ to control biofilms (exposed to PBS)

${ }^{\dagger} p<0.05$, significant differences when comparing exposure times for an antimicrobial agent

was evaluated. It was observed that the treatment with 4\% DMSO (v/v), concentration used to solubilize the extracts, had no effect on the bacterial cell viability (Table $3)$. There were no statistically significant differences when compared with PBS ( $p>0.05$ in all cases), or between exposure time ( $p>0.05$ in all cases) except for $F$. nucleatum, for which the effect of exposure time $(30 \mathrm{~s}$ versus $1 \mathrm{~min})$ was statistically significant $(p=0.012)$.

The CLSM analysis showed that, after $72 \mathrm{~h}$ of incubation on HA surfaces, the biofilm covered the disc surface as multicellular aggregates, exhibited a live/dead cell ratio of $1.13 \pm 0.50$ when dipped for $30 \mathrm{~s}$ and $1.10 \pm 0.16$ for 1 min in PBS (Control biofilms; Fig. 2 a, b). It could be observed that after $30 \mathrm{~s}$ exposures to both oenological extracts, cell vitality slightly decreased in the biofilms (live/dead cell ratio of $0.77 \pm 0.24$ for wine extract and $1.20 \pm 0.20$ for the grape seed extract; $p>0.05$ in both cases) (Fig. 2 e, g; Table 4). In the same way, after $1 \mathrm{~min}$ exposure to the wine extract (Fig. $2 \mathrm{f}$ ) and the grape seed extract (Fig. $2 \mathrm{~h}$ ), no reduction in viability was measured by CLSM (viability ratio $1.21 \pm 0.30$ and $1.30 \pm$ 0.47 , respectively; $p>0.05$; Table 4 ). No visual changes were observed when applying $4 \%$ DMSO solution for 30 $\mathrm{s}$ and $1 \mathrm{~min}$ (viability ratio of $0.87 \pm 0.30$ and $1.07 \pm 0.09$, respectively) (Fig. 2 c, d; Table 4). No statistically significant differences were observed when comparing wine and grape seed extracts at $30 \mathrm{~s}$ or $1 \mathrm{~min}$ or when comparing the exposure times ( $p>0.05$ for all cases).

\section{Discussion}

In the present study, the effect of red wine and oenological extracts in a validated oral biofilm model has been studied, demonstrating that wine solutions (dealcoholized or not) had a greater antimicrobial effects against A. actinomycetemcomitans and $P$. gingivalis when compared to the polyphenol rich oenological extracts. When comparing the oenological extracts, wine extract was more active against $P$. gingivalis and $F$. nucleatum, and the grape seed extract against $F$. nucleatum. In regards to the effects on total biofilm bacteria, wine solutions (dealcoholized or not) showed significant reductions in the live/dead cell ratios, in contrast, the oenological extracts did not evidence a relevant antibacterial effect.

Previous in vitro studies evaluating the antimicrobial effect of phenolic compounds from wines and oenological extracts have demonstrated significant effects against selected Gram-positive and Gram-negative pathogenic bacteria [42], enteric pathogens [43], pathogenic bacteria associated with respiratory diseases [44], or gut commensal, probiotic and pathogenic bacteria [45]. In the oral cavity, Toukairin and colleagues [46] reported that polyphenols, extracted from seeds and skin of wine grapes, had antibacterial effects against certain cariogenic bacteria, mainly through inhibition of the adherence of $S$. mutans and other streptococci. Similarly, Cueva and colleagues [44] incubated planktonic pure cultures of $S$. mutans and $S$ sobrinus with flavan-3-ols precursors, (+)-catechin and (-)-epicatechin (compounds present in the grape seed extract employed) and reported significant inhibition of bacterial growth. Daglia and colleagues studied the antiseptic effect of dealcoholized red wine in comparison with white wines, demonstrating a stronger action of red wines against oral streptococci, what reinforces the possible role of anthocyanins as bacteriostatic agents [25]. Recently, Esteban-Fernández and colleagues [21] showed antimicrobial activity against $P$. gingivalis, $F$. nucleatum and $S$. mutans growing planktonically when exposed to two wine phenolic compounds (caffeic and 


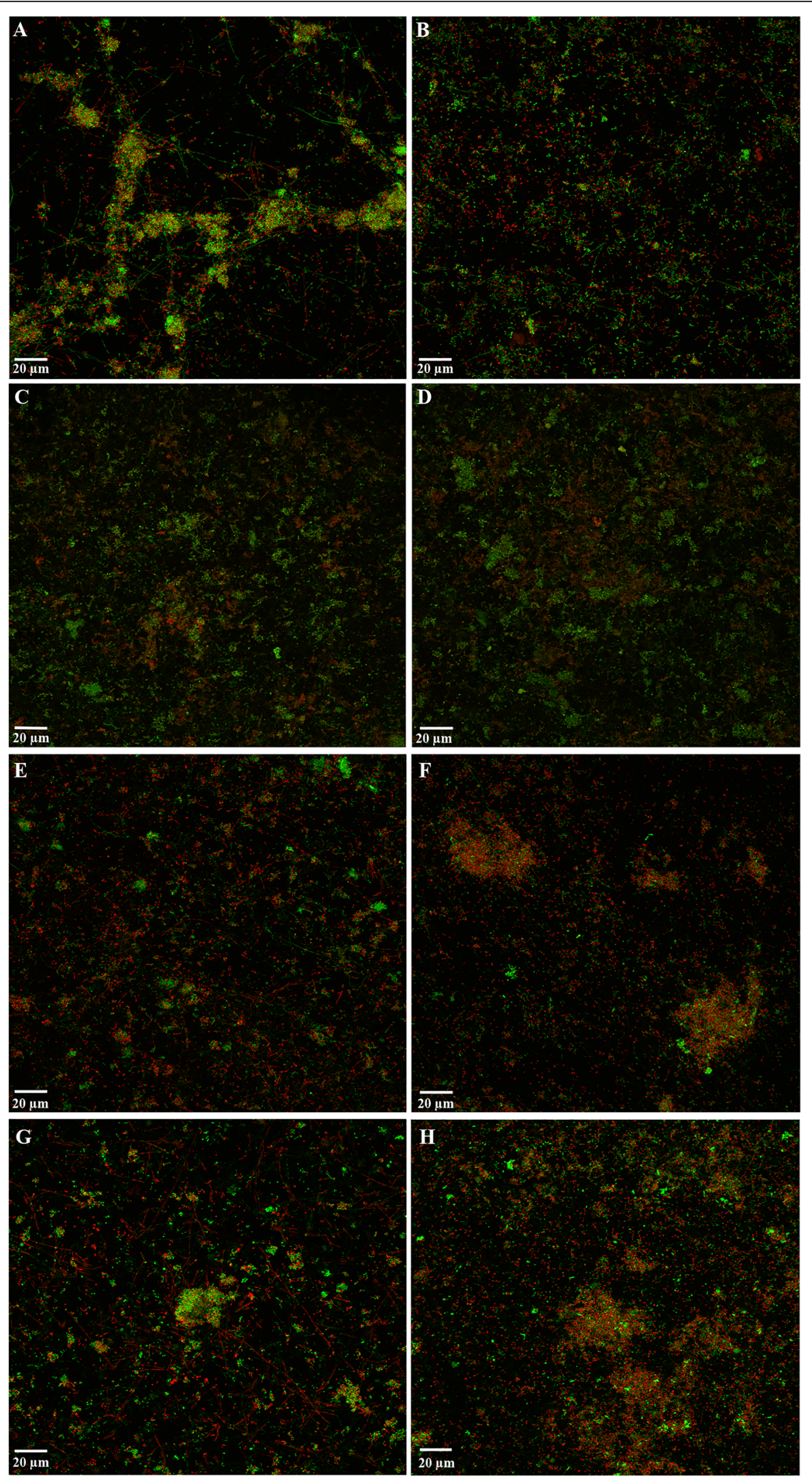

Fig. 2 (See legend on next page.) 
(See figure on previous page.)

Fig. 2 Maximum projection of Confocal Laser Scanning Microscopy (CLSM) images of $72 \mathrm{~h}$ biofilms, growth over hydroxyapatite surfaces, stained with LIVE/DEAD BacLight ${ }^{\text {TM }}$ Bacterial Viability Kit, after exposure to: $(\mathbf{a}, \mathbf{b})$ negative control $30 \mathrm{~s}$ and 1 min, respectively (phosphate buffer saline, PBS); (c, d) 4\% dimethyl sulfoxide (DMSO) solution $30 \mathrm{~s}$ and $1 \mathrm{~min}$, respectively; (e, f) wine extract $30 \mathrm{~s}$ and $1 \mathrm{~min}$, respectively $\left(\right.$ Provinols $^{\mathrm{TM}}, 20 \mathrm{~g} \mathrm{~L}^{-}$ $\left.{ }^{1}\right)$; and $(\mathbf{g}, \mathbf{h})$ grape seed extract (Vitaflavan', $\left.20 \mathrm{~g} \mathrm{~L}^{-1}\right)$. Scale bar $=20 \mu \mathrm{m}$

p-coumaric acids) and the same red wine and grape seed extracts (Provinols ${ }^{\mathrm{TN}}$ and Vitaflavan ${ }^{\circ}$, respectively) used in the present study.

These studies, however, have focused the study of their antimicrobial effect on species commonly detected in supragingival plaque, such as $S$. mutans, S. sobrinus or Lactobacillus spp., but not against the periodontal pathogens usually present in the subgingival microenvironment. Furthermore, most have used planktonic pure cultures and therefore, the reported effects could not be easy to be transferred to the oral environment, where bacteria live in highly complex communities, forming biofilms [47]. As mentioned above, Esteban-Fernández and colleagues [21], established the minimum inhibitory (MIC) and minimum bactericidal (MBC) concentrations (MIC/MBC) for P. gingivalis to Provinols ${ }^{\mathrm{Tw}}$ and Vitaflavan of $500 / \geq 1000 \mu \mathrm{g} \mathrm{mL}^{-1}$ for both extracts, and for $F$. nucleatum of $500 / 1000 \mu \mathrm{g} \mathrm{mL}^{-1}$ also for the referred extracts. However, in the present study, the observed antimicrobial activity can be considered as moderate against $P$. gingivalis and only statistically significant for $F$. nucleatum with both extracts, even at a high concentration $\left(20,000 \mu \mathrm{g} \mathrm{mL}^{-1}\right)$. These findings reinforce the importance of using biofilms models when testing antimicrobial

Table 4 Effect of the red wine phenolic extract (Provinols ${ }^{T M}$ ), rich in anthocyanins, and the oenological extract from grape seeds (Vitaflavan ) on the live/dead cell ratio (i.e. the area occupied by living cells divided by the area occupied by dead cells) of the whole biofilm obtained by Confocal Laser Scanning Microscopy (CLSM). PBS: phosphate buffer saline, DMSO: dimethyl sulfoxide

\begin{tabular}{|c|c|c|c|c|c|c|c|}
\hline \multirow{2}{*}{$\begin{array}{l}\text { Exposure } \\
\text { time }\end{array}$} & \multirow[t]{2}{*}{ Chemical treatment } & & \multirow{2}{*}{$\begin{array}{l}\text { Mean } \\
\text { Difference } \\
(I-J)\end{array}$} & \multirow{2}{*}{$\begin{array}{l}\text { Std. } \\
\text { Error }\end{array}$} & \multirow[t]{2}{*}{ Sig. ${ }^{a}$} & \multicolumn{2}{|c|}{ 95\% Confidence Interval for Difference } \\
\hline & & & & & & Lower Bound & Upper Bound \\
\hline \multirow[t]{12}{*}{$30 \mathrm{~s}$} & \multirow[t]{3}{*}{ PBS } & $4 \%$ DMSO & 0.250 & 0.256 & 1.000 & -0.520 & 1.020 \\
\hline & & Wine extract & 0.353 & 0.256 & 1.000 & -0.416 & 1.123 \\
\hline & & Grape seeds extract & -0.130 & 0.256 & 1.000 & -0.900 & 0.640 \\
\hline & \multirow[t]{3}{*}{$4 \%$ DMSO } & PBS & -0.250 & 0.256 & 1.000 & -1.020 & 0.520 \\
\hline & & Wine extract & 0.103 & 0.256 & 1.000 & -0.666 & 0.873 \\
\hline & & Grape seeds extract & -0.380 & 0.256 & 0.941 & -1.150 & 0.390 \\
\hline & \multirow[t]{3}{*}{ Wine extract } & PBS & -0.353 & 0.256 & 1.000 & -1.123 & 0.416 \\
\hline & & $4 \%$ DMSO & -0.103 & 0.256 & 1.000 & -0.873 & 0.666 \\
\hline & & Grape seeds extract & -0.483 & 0.256 & 0.463 & -1.253 & 0.286 \\
\hline & \multirow[t]{3}{*}{ Grape seeds extract } & PBS & 0.130 & 0.256 & 1.000 & -0.640 & 0.900 \\
\hline & & 4\% DMSO & 0.380 & 0.256 & 0.941 & -0.390 & 1.150 \\
\hline & & Wine extract & 0.483 & 0.256 & 0.463 & -0.286 & 1.253 \\
\hline \multirow[t]{12}{*}{$1 \mathrm{~min}$} & \multirow[t]{3}{*}{ PBS } & 4\% DMSO & 0.030 & 0.256 & 1.000 & -0.740 & 0.800 \\
\hline & & Wine extract & -0.110 & 0.256 & 1.000 & -0.880 & 0.660 \\
\hline & & Grape seeds extract & -0.197 & 0.256 & 1.000 & -0.966 & 0.573 \\
\hline & \multirow[t]{3}{*}{$4 \%$ DMSO } & PBS & -0.030 & 0.256 & 1.000 & -0.800 & 0.740 \\
\hline & & Wine extract & -0.140 & 0.256 & 1.000 & -0.910 & 0.630 \\
\hline & & Grape seeds extract & -0.227 & 0.256 & 1.000 & -0.996 & 0.543 \\
\hline & \multirow[t]{3}{*}{ Wine extract } & PBS & 0.110 & 0.256 & 1.000 & -0.660 & 0.880 \\
\hline & & 4\% DMSO & 0.140 & 0.256 & 1.000 & -0.630 & 0.910 \\
\hline & & Grape seeds extract & -0.087 & 0.256 & 1.000 & -0.856 & 0.683 \\
\hline & \multirow[t]{3}{*}{ Grape seeds extract } & PBS & 0.197 & 0.256 & 1.000 & -0.573 & 0.966 \\
\hline & & $4 \%$ DMSO & 0.227 & 0.256 & 1.000 & -0.543 & 0.996 \\
\hline & & Wine extract & 0.087 & 0.256 & 1.000 & -0.683 & 0.856 \\
\hline
\end{tabular}


activity, since bacterial cells in biofilms express different phenotypes, with greater resistance to antimicrobial agents [47-50]. Some studies have reported that the MIC of a bacteria can increase between 2 and 1000 times in a biofilm, when compared to the planktonic state [50], while other authors described 250 times greater MIC values for the same species growing in a biofilm when compared to planktonic state [51]. Sedlack and colleagues [51] described that bacterial resistance to antimicrobials appeared to be related to the maturation of the biofilms, since they demonstrated a progressive increase in resistance to the antibiotics as they matured, with a maximum resistance coinciding with the stationary phase of the growth of the biofilm. Therefore, the current work represents a further step in the study of the possible effects of polyphenols from red wine and oenological extracts in the management of periodontal diseases.

The results from the present study agree with those reported by Furiga and colleagues evaluating the activity of various extracts obtained from Vitis vinifera (Vitaceae) on a biofilm model composed of $S$. mutans, $S$. sobrinus, Lactobacillus rhamnosus, P. gingivalis, and F. nucleatum [22, 23]; and with those published by MuñozGonzalez and colleagues [28], describing the beneficial the bactericidal activity against $A$. oris, $F$. nucleatum, or $S$. oralis. of red wine and dealcoholized red wine.

\section{Conclusions}

This investigation has shown that the use of red wine and wine-derived extracts had a moderate antimicrobial impact in the total bacterial counts and counts of $A$. actinomycetemcomitans, $P$. gingivalis and $F$. nucleatum, when tested in an in vitro multi-species biofilm model. Although the antibacterial effects of red wine and winederived extracts was observed, at least 2 to $3-\log$ reduction of bacterial count would be necessary to ascertain the efficacy and/or availability of these tested agents as antibacterial agents. These results encourage further investigations on the potential use of natural agents in the prevention and treatment of periodontal diseases.

\footnotetext{
Abbreviations

$\mathrm{BHI}$ : Brain heart infusion culture medium; CFU: Colony-forming units; CLSM: Confocal laser scanning microscopy; DMSO: Dimethyl sulfoxide; DNA: Deoxyribonucleic acid; EtOH: Ethanol; HA: Hydroxyapatite; MBC: Minimum bactericidal concentration; MIC: Minimum inhibitory concentration; PBS: Phospate buffer saline; PMA: Propidium monoazide; qPCR: Quantitative polymerase chain reaction; UHPLC-ESI-MS/MS: Ultra-highperformance liquid chromatography-electrospray ionization-tandem mass spectrometry method
}

\section{Acknowledgements}

The authors would like to thank A. Cortés, from the Centre of Microscopy and Cytometry, University Complutense of Madrid, for his support in the technical microscopy services. A.E-F is the recipient of fellowship from the FPI-MINECO programme.

\section{Authors' contributions}

MCS, HRV and AEF contributed to conception and design of the study with the aid of EF, BB, MVMA, MS and DH, analysis and interpretation of data and drafted the manuscript. EF performed the statistical analyses. EF, BB, MVMA, MS and DH critically revised the manuscript. All authors reviewed the original draft and read and approved the final manuscript.

\begin{abstract}
Funding
This work was funded by the Spanish MINECO (AGL2015-64522-C2-R project) and Comunidad de Madrid (ALIBIRD-CM S2013/ABI-2728). None of the funders had any role in designing and/or conducting of the study; collection, management, analysis and interpretation of the data; and preparation, review or approval of the manuscript.
\end{abstract}

\begin{abstract}
Availability of data and materials
The data sets used and/or analyzed during the current study available from the corresponding author on reasonable request.
\end{abstract}

\section{Ethics approval and consent to participate}

Not applicable.

\section{Consent for publication}

Not applicable.

\section{Competing interests}

The authors declare that they have no competing interest.

\section{Author details}

'ETEP (Etiology and Therapy of Periodontal Diseases) Research Group, University Complutense, Madrid, Spain. ${ }^{2}$ Instituto de Investigación en Ciencias de la Alimentación (CIAL), CSIC-UAM, Madrid, Spain. ${ }^{3}$ Department of Dental Clinical Specialities (DDCS), Faculty of Odontology, Plaza Ramón y Cajal s/n Ciudad Universitaria, 28040 Madrid, Spain.

Received: 30 August 2018 Accepted: 29 May 2019

Published online: 21 June 2019

\section{References}

1. Socransky SS, Haffajee AD. Dental biofilms: difficult therapeutic targets. Periodontol 2000. 2002;28:12-55.

2. Teles R, Teles F, Frias-Lopez J, Paster B, Haffajee A. Lessons learned and unlearned in periodontal microbiology. Periodontol 2000. 2013;62(1):95-162.

3. Socransky SS, Haffajee AD. Periodontal microbial ecology. Periodontology 2000. 2005;38:135-87.

4. Tonetti MS, Van Dyke TE. Working group 1 of the joint EFPAAPW. Periodontitis and atherosclerotic cardiovascular disease: consensus report of the joint EFP/AAP workshop on periodontitis and systemic diseases. J Clin Periodontol. 2013:40 Suppl 14:S24-9.

5. Herrera D, Alonso B, Leon R, Roldan S, Sanz M. Antimicrobial therapy in periodontitis: the use of systemic antimicrobials against the subgingival biofilm. J Clin Periodontol. 2008;35(8 Suppl):45-66.

6. Sanz I, Alonso B, Carasol M, Herrera D, Sanz M. Nonsurgical treatment of periodontitis. J Evid Based Dent Pract. 2012;12(3 Suppl):76-86.

7. Rams TE, Degener JE, van Winkelhoff AJ. Antibiotic resistance in human peri-implantitis microbiota. Clin Oral Implants Res. 2014;25(1):82-90.

8. Van Strydonck DA, Slot DE, Van der Velden U, Van der Weijden F. Effect of a chlorhexidine mouthrinse on plaque, gingival inflammation and staining in gingivitis patients: a systematic review. J Clin Periodontol. 2012;39(11):1042-55.

9. Serrano J, Escribano M, Roldan S, Martin C, Herrera D. Efficacy of adjunctive anti-plaque chemical agents in managing gingivitis: a systematic review and meta-analysis. J Clin Periodontol. 2015;42(Suppl 16):S106-38.

10. Middleton E Jr, Kandaswami C, Theoharides TC. The effects of plant flavonoids on mammalian cells: implications for inflammation, heart disease, and cancer. Pharmacol Rev. 2000;52(4):673-751.

11. Mitjavila MT, Moreno JJ. The effects of polyphenols on oxidative stress and the arachidonic acid cascade. Implications for the prevention/treatment of high prevalence diseases. Biochem Pharmacol. 2012;84(9):1113-22.

12. Pandey KB, Rizvi SI. Plant polyphenols as dietary antioxidants in human health and disease. Oxidative Med Cell Longev. 2009;2(5):270-8.

13. Del Rio D, Costa LG, Lean MEJ, Crozier A. Polyphenols and health: what compounds are involved? Nutr Metab Cardiovas. 2010;20(1):1-6. 
14. Palaska I, Papathanasiou E, Theoharides TC. Use of polyphenols in periodontal inflammation. Eur J Pharmacol. 2013;720(1-3):77-83.

15. Nakamura K, Ishiyama K, Sheng H, Ikai H, Kanno T, Niwano Y. Bactericidal activity and mechanism of Photoirradiated polyphenols against grampositive and -negative Bacteria. J Agric Food Chem. 2015;63(35):7707-13.

16. Johnston MD, Hanlon GW, Denyer SP, Lambert RJW. Membrane damage to bacteria caused by single and combined biocides. J Appl Microbiol. 2003; 94(6):1015-23.

17. Rodriguez H, Curiel JA, Landete JM, de las Rivas B, Lopez de Felipe F, Gomez-Cordoves C, et al. Food phenolics and lactic acid bacteria. Int J Food Microbiol. 2009;132(2-3):79-90.

18. Campos FM, Couto JA, Figueiredo AR, Toth IV, Rangel AO, Hogg TA. Cell membrane damage induced by phenolic acids on wine lactic acid bacteria. Int J Food Microbiol. 2009;135(2):144-51.

19. Beecher GR. Overview of dietary flavonoids: nomenclature, occurrence and intake. J Nutr. 2003;133(10):3248S-54S.

20. Cueva C, Gil-Sanchez I, Ayuda-Duran B, Gonzalez-Manzano S, GonzalezParamas AM, Santos-Buelga C, et al. An integrated view of the effects of wine polyphenols and their relevant metabolites on gut and host health. Molecules. 2017;22(1):99.

21. Esteban-Fernandez A, Zorraquin-Pena I, Ferrer MD, Mira A, Bartolome B, de Llano DG, et al. Inhibition of Oral pathogens adhesion to human gingival fibroblasts by wine polyphenols alone and in combination with an Oral probiotic. J Agr Food Chem. 2018;66(9):2071-82.

22. Furiga $A$, Lonvaud-Funel $A$, Dorignac $G$, Badet C. In vitro anti-bacterial and anti-adherence effects of natural polyphenolic compounds on oral bacteria. J Appl Microbiol. 2008;105(5):1470-6.

23. Furiga A, Roques $C$, Badet C. Preventive effects of an original combination of grape seed polyphenols with amine fluoride on dental biofilm formation and oxidative damage by oral bacteria. J Appl Microbiol. 2014;116(4):761-71.

24. Thimothe J, Bonsi IA, Padilla-Zakour Ol, Koo H. Chemical characterization of red wine grape (Vitis vinifera and Vitis interspecific hybrids) and pomace phenolic extracts and their biological activity against Streptococcus mutans. J Agric Food Chem. 2007;55(25):10200-7.

25. Daglia M, Papetti A, Grisoli P, Aceti C, Dacarro C, Gazzani G. Antibacterial activity of red and white wine against oral streptococci. J Agric Food Chem. 2007;55(13):5038-42.

26. Hannig C, Sorg J, Spitzmuller B, Hannig M, Al-Ahmad A. Polyphenolic beverages reduce initial bacterial adherence to enamel in situ. J Dent. 2009; 37(7):560-6.

27. Wu CD. Grape products and oral health. J Nutr. 2009;139(9):1818S-23S.

28. Munoz-Gonzalez I, Thurnheer T, Bartolome B, Moreno-Arribas MV. Red wine and oenological extracts display antimicrobial effects in an oral bacteria biofilm model. J Agric Food Chem. 2014;62(20):4731-7.

29. Yamanaka A, Kouchi T, Kasai K, Kato T, Ishihara K, Okuda K. Inhibitory effect of cranberry polyphenol on biofilm formation and cysteine proteases of Porphyromonas gingivalis. J Periodontal Res. 2007;42(6):589-92.

30. Sampaio FC, Pereira Mdo S, Dias CS, Costa VC, Conde NC, Buzalaf MA. In vitro antimicrobial activity of Caesalpinia ferrea Martius fruits against oral pathogens. J Ethnopharmacol. 2009;124(2):289-94.

31. Badet C, Quero F. The in vitro effect of manuka honeys on growth and adherence of oral bacteria. Anaerobe. 2011;17(1):19-22.

32. Shahzad M, Millhouse E, Culshaw S, Edwards CA, Ramage G, Combet E. Selected dietary (poly)phenols inhibit periodontal pathogen growth and biofilm formation. Food Funct. 2015;6(3):719-29.

33. Munoz-Gonzalez I, Jimenez-Giron A, Martin-Alvarez PJ, Bartolome B, Moreno-Arribas MV. Profiling of microbial-derived phenolic metabolites in human feces after moderate red wine intake. J Agric Food Chem. 2013; 61(39):9470-9.

34. Sanchez-Patan F, Cueva C, Monagas M, Walton GE, Gibson GR, QuintanillaLopez JE, et al. In vitro fermentation of a red wine extract by human gut microbiota: changes in microbial groups and formation of phenolic metabolites. J Agr Food Chem. 2012;60(9):2136-47.

35. Sanchez-Patan F, Cueva C, Monagas M, Walton GE, Gibson GR, Martin-Alvarez PJ, et al. Gut microbial catabolism of grape seed flavan-3-ols by human faecal microbiota. Targetted analysis of precursor compounds, intermediate metabolites and end-products. Food Chem. 2012;131(1):337-47.

36. Sanchez MC, Llama-Palacios A, Blanc V, Leon R, Herrera D, Sanz M. Structure, viability and bacterial kinetics of an in vitro biofilm model using six bacteria from the subgingival microbiota. J Periodontal Res. 2011;46(2):252-60.
37. Keijser JA, Verkade H, Timmerman MF, Van der Weijden FA. Comparison of 2 commercially available chlorhexidine mouthrinses. J Periodontol. 2003; 74(2):214-8

38. Herrera D, Roldan S, Santacruz I, Santos S, Masdevall M, Sanz M. Differences in antimicrobial activity of four commercial $0.12 \%$ chlorhexidine mouthrinse formulations: an in vitro contact test and salivary bacterial counts study. J Clin Periodontol. 2003;30(4):307-14.

39. Sekino S, Ramberg P. The effect of a mouth rinse containing phenolic compounds on plaque formation and developing gingivitis. J Clin Periodontol. 2005;32(10):1083-8.

40. Sanchez MC, Marin MJ, Figuero E, Llama-Palacios A, Leon R, Blanc V, et al. Quantitative real-time PCR combined with propidium monoazide for the selective quantification of viable periodontal pathogens in an in vitro subgingival biofilm model. J Periodontal Res. 2014;49(1):20-8.

41. Sanchez MC, Llama-Palacios A, Fernandez E, Figuero E, Marin MJ, Leon R, et al. An in vitro biofilm model associated to dental implants: structural and quantitative analysis of in vitro biofilm formation on different dental implant surfaces. Dent Mater. 2014;30(10):1161-71.

42. Dolara P, Arrigucci S, Cassetta Ml, Fallani S, Novelli A. Inhibitory activity of diluted wine on bacterial growth: the secret of water purification in antiquity. Int J Antimicrob Agents. 2005;26(4):338-40.

43. Sugita-Konishi Y, Hara-Kudo Y, Iwamoto T, Kondo K. Wine has activity against entero-pathogenic bacteria in vitro but not in vivo. Biosci Biotechnol Biochem. 2001;65(4):954-7.

44. Cueva C, Mingo S, Munoz-Gonzalez I, Bustos I, Requena T, del Campo R, et al. Antibacterial activity of wine phenolic compounds and oenological extracts against potential respiratory pathogens. Lett Appl Microbiol. 2012; 54(6):557-63.

45. Cueva C, Moreno-Arribas MV, Martin-Alvarez PJ, Bills G, Vicente MF, Basilio A, et al. Antimicrobial activity of phenolic acids against commensal, probiotic and pathogenic bacteria. Res Microbiol. 2010;161(5):372-82

46. Toukairin T, Uchino K, Iwamoto M, Murakami S, Tatebayashi T, Ogawara H, et al. New polyphenolic 5'-nucleotidase inhibitors isolated from the wine grape "Koshu" and their biological effects. Chem Pharm Bull (Tokyo). 1991; 39(6):1480-3.

47. Marsh PD, Moter A, Devine DA. Dental plaque biofilms: communities, conflict and control. Periodontol 2000. 2011;55(1):16-35.

48. Gilbert P, Das J, Foley I. Biofilm susceptibility to antimicrobials. Adv Dent Res. 1997;11(1):160-7.

49. Costerton JW, Stewart PS, Greenberg EP. Bacterial biofilms: a common cause of persistent infections. Science. 1999;284(5418):1318-22.

50. Stewart PS, Costerton JW. Antibiotic resistance of bacteria in biofilms. Lancet. 2001;358(9276):135-8.

51. Sedlacek MJ, Walker C. Antibiotic resistance in an in vitro subgingival biofilm model. Oral Microbiol Immunol. 2007;22(5):333-9.

\section{Publisher's Note}

Springer Nature remains neutral with regard to jurisdictional claims in published maps and institutional affiliations.

Ready to submit your research? Choose BMC and benefit from:

- fast, convenient online submission

- thorough peer review by experienced researchers in your field

- rapid publication on acceptance

- support for research data, including large and complex data types

- gold Open Access which fosters wider collaboration and increased citations

- maximum visibility for your research: over $100 \mathrm{M}$ website views per year

At $\mathrm{BMC}$, research is always in progress.

Learn more biomedcentral.com/submission 